\title{
The Social Determinants of Health and Justice and the Aging in Prison Crisis: A Call for Human Rights Action
}

\author{
Tina Maschi (Corresponding Author) \\ Fordham University Graduate School of Social Service, Be the Evidence Project \\ 113 West $60^{\text {th }}$ Street, New York, United States \\ Tel: 1-845-664-3159Ｅ-mail: tmaschi@fordham.edu \\ Ronald H. Aday \\ Department of Sociology \& Anthropology, Middle Tennessee State University \\ 1301 E Main St, Murfreesboro, TN 37130, United States \\ Tel: 615-898-2125Ｅ-mail: Ronald.Aday@mtsu.edu
}

\begin{abstract}
Received: January 14, 2014 Accepted: March 26, 2014 Published: April 14, 2014
doi:10.5296/ijsw.v1i1.4914 URL: http://dx.doi.org/10.5296/ijsw.v1i1.4914
\end{abstract}

\begin{abstract}
The rapid growth of the incarceration of aging people in prison across the globe is particularly problematic in the United States, which has the largest incarceration rate per capita. This papers examines the aging in prison crisis through the lens of the social determinants of health, well-being, and justice. Case studies and promising practices are reviewed to assist in a coordinated human rights based response to address the aging in prison crisis at the grassroots, national, and international levels.
\end{abstract}

Keywords: human rights, incarceration, prison, aging, the rights of older persons, social determinants of health

"I was crippled when I was younger because my family member beat and molested me. I was tied to the basement poles beaten always, told over and over again you're a jail bird just like your father. This was so tightly put into my head it blurred everything I saw." - Quote from a 65 year old man in prison

"It's very tough surviving prison. The provoking, the unnecessary treatment, verbal abuse and violence only adds to the original sentence term to be served. Overcrowded conditions, poor medical service, lack of interaction with Administrative Staff is stammering." - Quote 
from a 68 year old woman in prison

\section{Background}

The rapid growth of the global incarceration of aging people in prison is particularly problematic in the United States, which has the largest incarceration rate per capita (ACLU, 2012). As of 2009, prison population rates per 100,000 were 760 in the United States, 624 for Russia, 153 in the United Kingdom, 119 in China, and 116 in Canada (OECD, 2010). In America, of the 2.3 million persons, approximately $16 \%(n=200,000)$ are aged 50 and older (Guerino Harrison, \& Sabol, 2012). In global corrections, the number of incarcerated adults aged 50 and older varies and has been steadily increasing over the past two decades (Aday, 2003; Carstairs \& Keon, 2009). Incarcerated adults, aged 50 and older, represent about 20\% $(n=2,800)$ of Canada's total prison population of 14,000 (Hale \& Swiggum, 2011). In Australia, of 19,082 general prison population, 7.4\% $(n=1,412)$ are aged 50 and older (Grant, 1999); in England and Wales, incarcerated adults aged 50 plus represent almost $11 \%$ $(n=6,417)$ of the total prison population (Ministry of Justice, 2010).

\section{The Aftermath of Punitive Policies}

The global rise in aging people in prison has been attributed to two central reasons: increases in the aging population coupled with the long-term aftermath of stricter sentencing and parole policies from the 1980s (Aday, 2003). For example, in America, the number of aging people is expected to continue to increase to $20 \%$ between 2010 and 2030 which would subsequently coincide with the increased number of aging people in prison (U.S. Census Bureau, 2010). In addition, conservative approaches to criminal justice from the 1980s resulted in stricter public and legislative policies, such as mandatory minimum sentences, truth in sentencing and laws, and strict drug and habitual offender laws (Aday \& Krabill, 2012). These restrictive policies widened that net in which many adjudicated individuals received longer mandatory minimum prison sentences including life sentences without parole. International advocacy groups, such as Human Rights Watch, argue that these sentences are unjust and disproportionate to the crime committed and do not account for age-related declining health (HRW, 2012). Currently, international correctional systems are grappling with how to provide the health related services to large numbers of aging people in prison, especially those aged 65 and older. Currently, most correctional systems are unprepared and under resourced to provide specialized services and long-term care or palliative and end-of-life care (Maschi, Viola, \& Sun, 2012).

It also is quite costly to detain older adults in prison. There are high medical expenditures for their institutional care especially those with serious illness, disabilities, or terminal illnesses (ACLU, 2012; UNODC, 2009). In America, for example, medical costs, such as medical, mental health, and dental care, are a large percentage of correctional budgets of which a disproportionate numbers of older adults use these services. Human Rights Watch reports that the costs of healthcare increase with age. In the United States, the average cost of care for the average prisoner is approximately $\$ 5,500$ compared to twice times more expensive for prisoners aged 55 to $59(\$ 11,000)$, and eight times expense for prisoners aged 80 and over (\$40,000; HRW, 2012). 


\section{Macrothink \\ International Journal of Social Work \\ ISSN 2332-7278 \\ 2014, Vol. 1, No. 1}

\section{Chronological Versus Biological Age Across the Globe}

An understanding of chronological versus biological age has important implications for global healthcare in corrections. The age at which individuals are defined as 'older' or 'elderly' differs across countries. Many societies view the chronological age of 65 as older because that is when most individuals are eligible to receive full pension or social security benefits. However, this chronological age designation is not uniform across the world because age has different meanings in various cultures (UNODC, 2009). Similarly, the age at which an incarcerated adult is defined as 'older' or 'elderly' varies across different countries.

Variations of age classification in corrections include in Australia, where age 50 is designated as older in prison. Incarcerated persons in the United States vary among states and incarcerated adults may be classified as "older adult" or "elderly" as low as age 50 (HRW, 2012). Other countries, such as the England classify age 60 to 65 as older. In contrast, Canada has a two level classification system in which being 'older' in prison is age 50 to 64 years and 'elderly' is aged 65 and above (UNODC, 2009). In general, this lower age classification is possibly because the average person in prison may experience accelerated decrements in their health status equivalent to community-dwelling adults who are 15 years older (ACLU, 2012). This process of accelerated aging is corroborated by evidence from international prison studies showing that older adults in prison have significantly higher rates of physical and mental health decline compared to younger prisoners or older adults of a comparative age in the community (Aday, 2003; Maschi et al., 2013). This rapid decline of incarcerated older adults' health has been attributed largely to their high risk personal histories, chronic health conditions, poor health practices, such as poor diets and smoking, alcohol and substance abuse, coupled with the stressful conditions of prison confinement, such as prolonged exposure to overcrowding, social deprivation, and prison violence (Aday \& Krabill, 2012). Theses combined personal and social environmental risk factors significantly increase the likelihood of the early onset of serious physical and mental illnesses, including dementia, among people in prison (Maschi, Kwak, Ko, \& Morrissey, 2012). 
Table 1. Sample Case Vignettes of Older People in Prison: Jorge, Mary, and Joseph

1. Jorge is a 56-year-old male from Puerto Rico and the youngest of nine children. He has a history of trauma and criminal offending that has included the unexpected death of his father at age 5, childhood sexual victimization, poverty, prostitution, drug dealing, substance abuse (heroin addiction), and recidivism (incarcerated two times). At age 17, he reported committing armed robbery to support his heroin addiction and was sentenced to 20 years in prison. During his prison term, he continued to use drugs. He violated parole within fifteen months of release after being charged with sexual offense of a minor and possession of controlled dangerous substances, and as a result, is now serving his second and current 45-year sentence. In prison, he has spent eight of the past fifteen years in solitary confinement. He perceives prison as "an overcrowded monster" designed to hold, degrade and punish people. He views the staff as disinterested and disengaged and is despondent over the limited access to counseling and education rehabilitative services. Jorge was diagnosed with cancer six months ago while in prison and is projected to receive parole in 14 years when he is in his late seventies. He has not had any contact with family in over 5 years and reports feeling depressed.

2. Mary is a 64-year-old, Caucasian, Catholic woman who is incarcerated in a maximum security facility for women. She identifies herself as a lesbian. As a child, she experienced the divorce of her parents, abandonment by her mother, and sexual, physical, and verbal abuse by her father, whom she described as having serious mental health issues. At age 25, Mary married a man ten years younger, had two children, and divorced. This is her first criminal conviction, and she is serving a ten-year prison sentence $(85 \%$ minimum) for conspiracy and the attempted murder of her abusive husband, which she describes as in self-defense. Mary describes this sentence as unfair and unjust based on mitigating circumstances. She has a medical history of hypertension, vision impairment, and osteoporosis that makes it difficult for her to walk or use a top bunk bed. At age 64, Mary's extensive dental problems have resulted in a premature need for dentures. She describes her current prison experience as "degrading, especially the way correctional officers treat inmates." Although she reports feelings of depression and despair, Mary reports that she copes with her prison experience by "finding meaning" in it through spirituality. Despite her ill health, Mary is resistant to using prison health care services. Her projected parole date is in two years, when she will be 66 years old. Because of the distance, Mary has not had any in-person visits with her family members since her incarceration but corresponds monthly by mail with her two adult children and four grandchildren every three months by phone. She says that she misses her family immensely.

3. Joseph is a 66 year old Caucasian gay male of Irish and Polish descent; his family has an intergenerational history of alcoholism and is a Vietnam war veteran. As a child he experienced 'extreme' corporal punishment from his parents and was fearful of communicating with his parents because of it. As a child, Joseph was sexually molested for years by his little league manager. At age 13, he made a conscious decision to "get tough" to protect himself; at 18 he joined the Marine Corp. After his release, Joseph witnessed a man in a bar offering cocaine to several young girls who he believed would be sexually molested. In a blinding rage, he took the man outside the bar with another peer and murdered the man. In prison, Joseph spent time in administration segregation and solitary confinement. During these periods of isolation he describes engaging in self-reflection. His recent visit to the prison infirmary showed that he had signs of cognitive impairment, suggestive of dementia. He is serving a life sentence in prison.

\section{Diversity and Aging People in Prison}

Older adults in prison are a heterogeneous group and may vary by global regions. Incarcerated adults aged 50 and older often differ based on characteristics such as age, race/ethnicity, gender, sexual orientation, mental and physical health statuses, and military and criminal offending histories. This diversity has implications inter-professional prevention, assessment, and intervention with older adults in the criminal justice system. For example, in 
the U.S. prison population aged 50 and older, the vast majority are men (96\%) compared to women (4\%) and are disproportionately racial ethnic groups (black $=45 \%$, Latino $=11 \%$, $10 \%=$ other) compared to whites (43\%; Guerino et al., 2011). Health status also varies; some individuals have functional capacity while others suffer from disabilities or serious, chronic, and terminal illnesses such as HIV/AIDs, cancer, and dementia or mental health (e.g., depression, anxiety, psychosis) and substance use problems (36\%; Maschi, Sutfin, \& O'Connell, 2012). The majority report a history of victimization (especially the LGBT population), grief and loss, chronic stress, prior to and during prison, including veterans' exposed to combat, and varying levels of coping and social support (Sampson \& Laub, 2003; Maschi et al., 2013). Family relationships also differ among older people in prison. Some older adults are married or partnered, divorced/separated, or widowed. Most older adults in prison also are parents and grandparents of which separation from their families is a significant form of distress, especially for older women (Aday \& Krabill, 2011; Maschi et al., 2012). Table 1 provides three case vignettes that illustrate some of the similarities and differences found among aging people in prison.

Histories of cumulative trauma and stress are an important consideration among older people in prison, especially for older women (Aday \& Krabill, 2011). Incarcerated older men and women on average reported three traumatic or stressful life experiences that occurred in prison or in the community. Many older adults report lingering subjective distress associated with these events, including events from childhood, that influences their current state of health and well-being. Their life history trajectories also suggest that power, access to services and justice often proceed imprisonment and the trauma of incarceration may only exacerbate mental distress and an adverse stress response and disenfranchised grief (Maschi et al., 2011, 2012). Evidence also suggests that experiences of trauma and stress vary by age. For example, Maschi and colleagues (2011) study of examined significant differences in lifetime experiences of trauma and stress between incarcerated young adults aged 18 to $24(n=38)$ and adults aged 50 and older $(n=2)$. They found that incarcerated older adults were more likely to report experiencing a natural disaster, life-threatening illness, or the death of a loved one. In contrast, their younger counterparts were more likely to report histories of witnessing physical assault.

Another important issue with social work and interprofessional practice are population variations of older people in prison based on length of prison term and preparedness for prison placement and community reintegration. Three major types of older people in prison include: the long termer (a person with 20 or more years served), the lifer (life sentence), the chronic recidivist (two or more incarcerations), and the later life offender (first convicted in old age). Regardless of the age they are released from prison, the formerly incarcerated older adults continue to experience the collateral consequences of incarceration and ageism post release that creates barriers for them to obtain health, economic and social care needs, such as healthcare (including nursing home placement), housing, employment, housing, and social welfare benefits (Aday, 2003; Maschi et al., 2012). 


\section{A Human Rights Response: Integrating Health, Social Care, and Justice}

Bridging older adults in prison to their families and communities raises issues related to the right to health, social care, and elder and intergenerational justice. The pathways to prison vary for aging people in prison including one or more cumulative social inequalities, such as disadvantages based on age, race, education, socioeconomic status, gender, disability, legal or immigration status. These accumulated inequalities can influence their access to health and social services, economic resources, social inclusion, and justice across the life course. As the grassroots human rights movement is gaining momentum in its efforts to advocate for the rights of older persons and the right to health, the global social work and inter-professional practice community is challenged to think creatively and out of the penitentiary box on how to coordinate effective intersectoral collaboration, holistic care, care transitions, and local and global advocacy for older adults in prison and post release.

The social determinants of health disparities (e.g., poverty, chronic stress, poor nutrition) and criminal justice involvement coupled with poor social and environmental conditions of confinement for older adults, are a type of elder abuse and neglect (WHO, 2012). The World Health Organization (2012) defines elder abuse as a "a single, or repeated act, or lack of appropriate action, occurring within any relationship where there is an expectation of trust which causes harm or distress to an older person" (p. 1). Common among definitions of elder abuse, it may take many forms, such as physical, sexual, psychological, emotional, financial exploitation, and intentional or unintentional neglect, including medical neglect (UN, 2012). Chronic victimization, medical neglect, lack of rehabilitation services and discharge planning exacerbate physical and mental illnesses and are a violation of human rights, especially the right to health, well-being, social security, family, culture, and safety, including protection from torture or cruel and unusual punishment or elder abuse (UN, 1948). Social work could take a leading advocacy role in extending elder justice to older adults in prison.

\section{United Nations Guidelines: Blueprint for Action}

The Report of the United Nations High Commissioner for Human Rights (2012) advocates that special consideration be given to aging people in prison. The report notes the accumulated disadvantages inherent in older people's past and current experiences of mistreatment and social disadvantage and grave human rights violations often found in prison settings. Fundamental human rights values that often area violated among older people are dignity and respect for all persons and the indivisible and interlocking holistic relationship of all human rights in civil, political, economic, social, and cultural domains (UN, 1948). In the movement towards a Convention on the Rights of Older Persons, proposed language for a new instrument are framed by conceptions of equality, respect, autonomy, and dignity (UN, 2012). Areas of protections of older persons that are underscored for those in prison include: age discrimination, legal capacity and equal recognition before the law, conditions of institutional and home-based long term care, violence and abuse, access to productive resources, work, food, and housing, social protection and the right to social security, right to health and palliative and end-of-life care, disabilities in old age, access to justice and legal rights. The United Nations classifies 'older prisoners' as a special needs population along 
with racial/ethnic minorities, persons with disabilities or terminal illnesses, homosexuals (GBLT), and death row inmates with specific non-binding guidelines for their treatment that include care transitions (UNDOC, 2009).

Existing United Nations documents, such as the Standard Minimum Rules on the Treatment of Prisoners (UN, 1977) and the Handbook of Special Needs Prisoners (UNDOC, 2009), provide non-enforceable guidelines that address the needs of older people in prison. These guidelines include access to prison rehabilitation, physical and mental health care, geriatric specific care, and family programming and community linkages to services. The community reunification of older people with their families also is a critical issue. The collateral consequences of incarceration, such as lack of access to family contact, housing, healthcare, employment, and social security and benefits, make it challenging for older adults to readjust, especially those with longer or life prison terms (Aday, 2005; Higgins \& Severson, 2009; Maschi et al., 2013). Individual prisons, states, and countries can use these guidelines to determine to what extent their programming addresses quality of life and safety for their aging prison population.

\section{Realizing Rights: Promising Compassionate Policies and Laws}

Some of these United Nations guidelines that affect aging prisoners can be evidenced in 'compassionate' policies and laws in some countries. China recently passed the 2010 Criminal Law of China that bans the death penalty for people aged 75 or older, except in the case of extreme homicide (Guo, 2011). The United States has federal and state policies, often referred to as discretionary parole, inmate furloughs, or medical or compassionate release policies. Since 2009, geriatric release provisions in the U.S. included one more of the following criteria: minimum age, physical or mental health status, and minimum sentence and low level criminal risk clauses. However, in the United States there have been barriers to their effective implementation even for older, infirm, and seriously ill older adults in prison, which reduces their rights to dignity and respect even when dying. These barriers include the poor design of the laws (e.g., narrow eligibility criteria), implementation procedures (e.g., bureaucratic red tape), and the reluctance of politicians to remedy the situation due to public pressure (Chiu, 2010).

In 1998, the United States Supreme Court held in Pennsylvania Dept. of Corrections v. Yeskey, 524 U.S. 206 (1998) that the Americans with Disabilities Act (ADA) applies to persons in prisons and jails. Prison wardens in the United States stated that compliance with the Americans with Disabilities Act inadvertently improved their services for older prisoners (NIC, 2010). ADA compliant standards in prisons have included environmental modifications, such as hand rails in inmate cells, showers, hallways and communal settings. Some prisons have created specialized geriatric services to best ensure comprehensive services for incarcerated older adults (Harrison, 2011).

\section{Innovative Solutions}

\subsection{Fostering Care Transitions from Prison to Community}

Transitioning older adults from prison to the community can be challenging. For example, 
older adults who served long prison sentences may experience institutionalization (e.g., not knowing how to survive outside of prison; Davies, 2011). Successfully reunification of incarcerated older adults to their families and communities may be compounded by other health and/or mental health issues, lack of family and peer support, substance use, lack of available community medical, mental health, and substance abuse services, lack of financial resources and access to social welfare benefits (including retirement), suitable housing options, such as assisted living and nursing homes, and available transportation (Williams et al., 2012).

Some aging people who are released from prison may have limited functional capacities and may need assistance with activities of daily living, such as taking care of one's personal hygiene and getting dressed. Other seriously or terminally ill older adults may need long-term institutional care, such as placement in a skilled nursing home. Some terminally ill persons may need hospice placement in the community to address their palliative and end-of-life care (Mesurier, 2011). However, barriers to placement in nursing homes and hospices may exist due to the stigma and discrimination against individuals with criminal offense histories, especially for more serious offenses, such as arson and sex [crimes] offenses. For able-bodied older adults, attainment of employment or job training is another factor for successful community reintegration. This criminal history may create barriers to attaining employing, housing, or even placement in nursing homes or hospices (Maschi et al., 2013).

\subsection{Select Global Practices}

Despite the challenges, promising practices have emerged across the globe that are guided by human rights principles and practices that foster the health and well-being of older adults. Worldwide, there are some innovative geriatric programs in prisons and post community reintegration. Promising practices often include comprehensive case management services for medical, mental health, substance abuse, family, social services, housing, education or vocational training, spiritual counseling, exercise and creative arts programs, employment and/or retirement counseling. Program specific aspects include one or more of the following: 'age' and 'cognitive capacity' sensitive environmental modifications (including the use of segregated units), interdisciplinary staff and volunteers trained in geriatric specific correctional care, complimentary medicine, specialized case coordination, the use of family and inmate peer supports and volunteers, mentoring, and self-help advocacy group efforts. Due to space limitations, only select global programs are highlighted here. 
Table 2. Program Components for a Geriatric Prison Program

1. Diversion activities. Diversion activities are a major segment of the program. Crocheting, knitting, beading, and latch-hook rugmaking provide activity that is not only cognitively stimulating, but affords excellent physical therapy for arthritic hands and fingers

2. Culturally responsive cognitive interventions. Cognitive interventions, include creative writing, Spanish language study group, ethnodrama, and culturalarts group. The groups produce a newsletter and poetry journal, which are edited by the group members.

3. Substance abuse/addictions groups. Weekly meetings of 12-step groups including Alcoholics Anonymous, Narcotics Anonymous, and SexualCompulsives Anonymous which a re facilita ted by volunteer sponsors.

4. Psychoeducation. Weekly seminars are held that address a ging, health and wellness, sexua lity, life skills, cooking, menu-planning and healthy life choices, or other relevant activities.

5. Animal assisted therapy/end-of-life care. Volunteers provide animal assisted therapy (individually and in group. Animal-assisted therapy targets physical, occupational, speech and psychotherapies, special education, pain management issues, and end of life support.

6. Physical exercise. Program participants are scheduled for daily exercise activities. These activities include: wheelchair softball, basketball, or volleyball; a erobics, tennis, measured-distance walking, weight-lifting, stationary bicycle, billiards, ping-pong, horseshoes, or dancing.

7. Peer support groups/ Vet-to-Vet. Veteran Volunteers assist members with writ ing and producing artwork about their war experiences

8. Spiritual wellness. Spiritual wellness consists of traditional religious activities by staff or volunteers or peer support members. Bereavement services are provided for when the dea th of a family member or peer in prison occurs.

9. Correctional mental health activities. Formal correctional programs facilitated by both staff and community volunteers are available to program participants. These programs include victim awareness, stress management, anger management, conflict resolution, relationship skills, health-related recovery, commitment to change, trauma and recovery, addictions prevention education, sex offender trea tment, parenting and grand parenting classes, and special populations programs.

10. Prison legal services. Prison legal services provide program participants access to pro bono lawyers and social workers who are versed in elder and prison rights and law and case management services. Pro gram participants can seek consultation or representation for appeals based on sentencing, parole release, or geriatric, medical, and compassionate release. The prison Ombudsman represents cases of interpersonal victimization and institutional abuse. Community advocates who monitor cases based on the Prison Rape Elimination Act also are available to incarcerated persons at the facility, including program participants.

11. Family visiting programs. The family visiting program provides extended time with family members, which includes spouses and partners, children, and grandchildren. Families can request transportation services from faith-based volunteers if there is no access to public transportation to get to the facility. An option for televisiting was available for participants, such as Mary, whose family lived at a distance that did not enable them to visit her in person. For participants without family members that can visit, peer visits and volunteer visitors can be arranged based on request.

12. Restorative justice/reconciliation and forgiveness groups/long termers and lifers group. The program also offers a session for reconciliation and forgiveness. It uses a narrative style writing and group reflection for individuals to process their crime, especially violent or sexual offenses that resulted in the harm or death to another person or persons. For participants with life sentences, a weekly lifers group is offered.

13. Education and Vocational Training. Program participants may choose from a range of vocational services to obtain GED or high school diplomas, college degrees, and vocationaltraining in occupations, such as the culinary arts and select trades.

\subsection{The True Grit Program (USA)}

The True Grit Program in Nevada (USA) is a prison-based structured living program that attempts to foster older prisoners' well-being. The program, set in a geriatric sociocultural environment, was designed to enhance physical health (using creative arts, recreational and physical therapy activities); mental and social well-being (using group and individual therapy), human agency and empowerment (self-help modalities), spiritual well-being (using a prison chaplain and volunteers), and successful community reintegration (using discharge planning). Research evidence suggests the program is effective in increasing psychological and social well-being while in prison (Harrison, 2011). The program also shows a $0 \%$ recidivism rate for program graduates (Maschi et al., in press). For a detailed description of the program components and sample intervention plan see Tables 2 and 3. 


\section{Macrothink}

Table 3. Intervention Plan

\begin{tabular}{|c|c|c|c|}
\hline Intervention & Jorge & Mary & Joseph \\
\hline Treatment Goals & $\begin{array}{l}\text { 1. Increase root, } \\
\text { cognitive, } \\
\text { physical, } \\
\text { emotional, } \\
\text { social, } \\
\text { spiritual, } \\
\text { participatory } \\
\text { well-being. } \\
\text { 2. Reduce } \\
\text { disciplinary } \\
\text { infractions to } \\
\text { zero }\end{array}$ & $\begin{array}{l}\text { 1. Increase root, } \\
\text { cognitive, } \\
\text { physical, } \\
\text { emotional, } \\
\text { social, } \\
\text { spiritual, } \\
\text { participatory } \\
\text { well-being. } \\
\text { 2. Increase } \\
\text { preparedness } \\
\text { for community } \\
\text { reintegration }\end{array}$ & $\begin{array}{l}\text { 1. Increase root, } \\
\text { cognitive, } \\
\text { physical, } \\
\text { emotional, } \\
\text { social, spiritual, } \\
\text { participatory } \\
\text { well-being. }\end{array}$ \\
\hline \multicolumn{4}{|l|}{ Programming Assigned } \\
\hline Arts-Based Diversion Activities & $\mathrm{X}$ & $\mathrm{X}$ & $\mathrm{X}$ \\
\hline $\begin{array}{l}\text { Culturally Responsive Cognitive } \\
\text { Interventions }\end{array}$ & $\mathrm{X}$ & $\mathrm{X}$ & $\mathrm{X}$ \\
\hline $\begin{array}{l}\text { Substance } \\
\text { Groups }\end{array}$ & $X$ & $\mathrm{X}$ & $X$ \\
\hline Psychoeducation & $X$ & & $\mathrm{X}$ \\
\hline Animal Assisted Therapy & $X$ & $\mathrm{X}$ & $\mathrm{X}$ \\
\hline $\begin{array}{l}\text { End-Of-Life Care/Grief and } \\
\text { Bereavement }\end{array}$ & & & \\
\hline Physical Exercise & $\mathrm{X}$ & $\mathrm{X}$ & $\mathrm{X}$ \\
\hline Peer Support Groups/Vet to Vet & & & $X$ \\
\hline Spiritual Wellness & $X$ & $\mathrm{X}$ & $\mathrm{X}$ \\
\hline Mental Health Activities & $\mathrm{X}$ & $X$ & $\mathrm{X}$ \\
\hline $\begin{array}{l}\text { Prisoner Legal Services \& Victim } \\
\text { Rights }\end{array}$ & $\mathrm{X}$ & $\mathrm{X}$ & $\mathrm{X}$ \\
\hline $\begin{array}{l}\text { Family/Peer/ Volunteer Visiting } \\
\text { Program }\end{array}$ & $\mathrm{X}$ & $\mathrm{X}$ & $\mathrm{X}$ \\
\hline $\begin{array}{l}\text { Restorative } \\
\text { Justice/Reconciliation/Forgiveness }\end{array}$ & $\mathrm{X}$ & $X$ & $\mathrm{X}$ \\
\hline $\begin{array}{l}\text { Education and Vocational Training } \\
\text { Discharge Planning }\end{array}$ & $\mathrm{X}$ & $\begin{array}{l}X \\
X\end{array}$ & $\mathrm{X}$ \\
\hline Lifers and Long Termers Group & $\mathrm{X}$ & & $\mathrm{X}$ \\
\hline
\end{tabular}

\subsection{Hocking Correctional Facility (USA)}

The Hocking Correctional Facility (HCF) in Ohio (USA) addresses the prison and community reintegration needs of older prisoners. Offering one-stop wrap around services, it includes a pre-release program which provides inmates with information on social security or welfare benefits, job seeking skills, housing placement services; employment training, property maintenance; self-care and psycho-educational classes (for topics that address age 


\section{Macrothink}

related issues, such as the physical, psychological and social processes of aging), and general education and literature courses. The facility also provides staff training with knowledge and skills to deal effectively with geriatric populations, including chronic and terminal illnesses. Community reintegration is an active component of services so that older adults have the necessary resources, including an approved placement in nursing homes if older adults' declining health status necessitates this placement (Aday \& Krabill, 2012).

\subsection{The California Men's Colony (USA)}

California Men's Colony in San Luis Obispo, California (USA, medium secure care facility) has a dementia unit that can be described as a 'peer support'. The program aides consist of six volunteer inmates or 'social aides'. Their role is to act as 'buddies' to fellow prisoners with dementia. Their responsibilities include to ensure they receive medical care, provide social support, and provide protect since in prison older adults with cognitive disorders are vulnerable to victimization (Ubelacker, 2011).

\subsection{Recoop (England)}

In England, the Resettlement and Care for Older Ex-Offenders (Recoop) is a program that promotes older adults' health and well-being by providing care, resettlement and rehabilitation services of older offenders and ex-offenders. It does so through the provision of support services, advocacy, financial advice, mentoring on issues such as employment and training and advice on housing and health that will enable them to take control of their lives and remain free from re-offending and minimizing social isolation (Cooney \& Braggins, 2008).

\subsection{Reintegration Effort for Long-term Infirm and Elderly Federal Offenders' (RELIEF)}

Program (Canada) The RELIEF Program was established in Canada in 1999 to facilitate the transition of elderly and infirm prisoners into the community. The program was designed based on human rights and social justice values of dignity and worth of the person and respect to the dying. The program trains formerly incarcerated people and caregivers to provide compassionate peer support to the formerly incarcerated persons who are dying (Maschi et al., 2012).

\subsection{Long Bay Correctional Facility (Sydney, Australia)}

In Sydney, Australia, Alizheimer's Australia, North South Wales, the Justice Health \& Forensic Mental Health Network at Long Bay Correctional Complex and other agencies have formed a collaboration to develop and improve care and treatment for their prison population with cognitive impairment and dementia. Their current level of service provision include an inpatient facility in Existing in Long Bay Hospital for incarcerated elders who long-term supported care and a geriatric specific unit with support from a disability service to provide independent living option for able-bodied incarcerated elder. They also have implemented a state-wide Aged Care Bed Model to facilitate appropriate placement of seriously ill incarcerated older adults, including with dementia, in prison or community placement services. Their services include interprofessional teams that include physiotherapists, geriatricians, psychogeriatricians, general practitioners, podiatrists, optometrists, dentists, 


\section{$\triangle$ Macrothink}

psychologists, occupational therapists, audiologists, and specialised aged-care nurses and includes a research arm with local universities to conduct evaluation research designed to improve services In addition to a commitment to ongoing service development, JH\&FMHN are also collaborating with universities in NSW to conduct research related to improving service provision for patients with dementia. A recent research initiative saw the development of tools and procedures related to the identification, assessment and management of patients with dementia in NSW prisons (Alzheimer's Australia NSW, 2014).

\section{Seamless Systems of Care and Care Transitios}

Older adults and their families and communities have the right to care transitions that foster health and well-being, safety, and family bonds. Yet, a combination of individual, family, and community vulnerabilities often complicate the building of bridges between prison and community. The context with which incarcerated people experience their reentry is critical: income, employment, housing, safety, and access to health and social services influence the likelihood for successful reintegration within communities (La Vigne \& Cowan, 2005). While incarcerated, the ability to be employed and contribute to partners and children, and to provide for the health and welfare of families, impacts anticipatory stress (Maschi et al., 2012). Released prisoners can expect to earn no more than half of what they made before incarcerated and the impact on families can be economically detrimental; research shows that family income is a major indicator of future success for children, and combined with the associated school problems children with an incarcerated parent experience, the intergenerational costs become incalculable (PCT, 2010).

Thus, for older adults in prison, especially women, who still have responsibility for children less than 18 , moving from prison to work is critical. Over $10 \%$ of those returning to prison for violations are sent back because of the inability to pay child support (PCT, 2010). Despite this, even for those persons who would normally be approaching 'retirement age,' work takes on increased significance since they often have no other income or family support for retirement. Therefore, programs and policies that support work initiatives and training, or provide support from community based coalitions that bridge the formerly incarcerated and employers, are critical to securing and sustaining employment.

Within the prison population there are those who are at greater risk for recidivism, especially those who were homeless, suffer from physical and/or mental health issues, or present with alcohol or drug use at time of offense. Programs that combine rehabilitation services with employment and housing demonstrate higher levels of reentry success and lower levels of drug relapse (PCT, 2010). Providing disease prevention programs and consistent medical care while incarcerated and anticipating transitions to community based care, including health homes designed for vulnerable Medicaid beneficiaries, or Accountable Care Organizations for elderly who suffer from chronic conditions, are critical for removing health barriers that prevent newly released prisoners from seeking employment, housing, or renewing family and community relationships. Improving care while incarcerated is an important step towards reducing overall costs of incarceration and reentry; costs for care while incarcerated are two to eight times higher for those between the ages of 55 to 80 (Maschi et al., 2012). Policy 
changes are also required at the federal and state level if we are to truly have any success at reintegrating the formerly incarcerated. Currents laws and policies often bar the formerly incarcerated with employment opportunities, receipt of government benefits that provide housing, education, and even food stamps, as well as limited to no opportunity for removing criminal records and histories (Maschi et al., in press; Western, 2008).

\section{Future Directions}

The biggest challenges for interdisciplinary professionals and programs is to be competent at working across the aging, social service, public health and criminal justice sectors of care. Although the extent to which some skills are used depends upon where a professional is "positioned" in the system (e.g., clinical social worker in prison, reentry program administrator), it involves having competencies in gerontological practice, physical and mental health assessment and intervention, case management, interdisciplinary collaboration, discharge planning, and legal and policy issues.

Due to the complex nature of individual and social-structural level factors or social determinants of health impacting the pathways to prison, prison conditions, and transitional planning, an interdisciplinary response that includes doctors, nurses, psychologists, social workers, peer companions, family, and communities is critical. The grassroots, multiple stakeholder perspectives, as demonstrated in promising programs, are critical to foster health and well-being among older adults and to help them maintain family and community bonds while in the criminal justice system. Professionals, such as social workers or nurses, who conduct needs assessments, can identify the potential barriers in their local communities and identify community based organizations and members who can help address them.

Official statistics suggest that compared to incarcerated younger people, incarcerated older adults have the lowest likelihood of recidivating (Langan \& Levin, 2002). Given this finding of lower re-offending the policy initiatives outlined above become more viable. However, more conservative monitoring approaches, such as the use of ankle bracelets, allow the option of diversion from incarceration or the early release of older prisoners. Both diversion options are much less expensive than warehousing them in prison and may more easily address trauma, mental health, and health issues, greatly reducing the costs associated with caring for older inmates. For more dangerous older adult populations, the establishment of geriatric units in which older adult prisoners in special units are separate from younger prisoners may better provide for their special needs; although it will be critical for correctional staff members who work with this population to receive specialized training to effectively provide care (Dawes, 2008). 


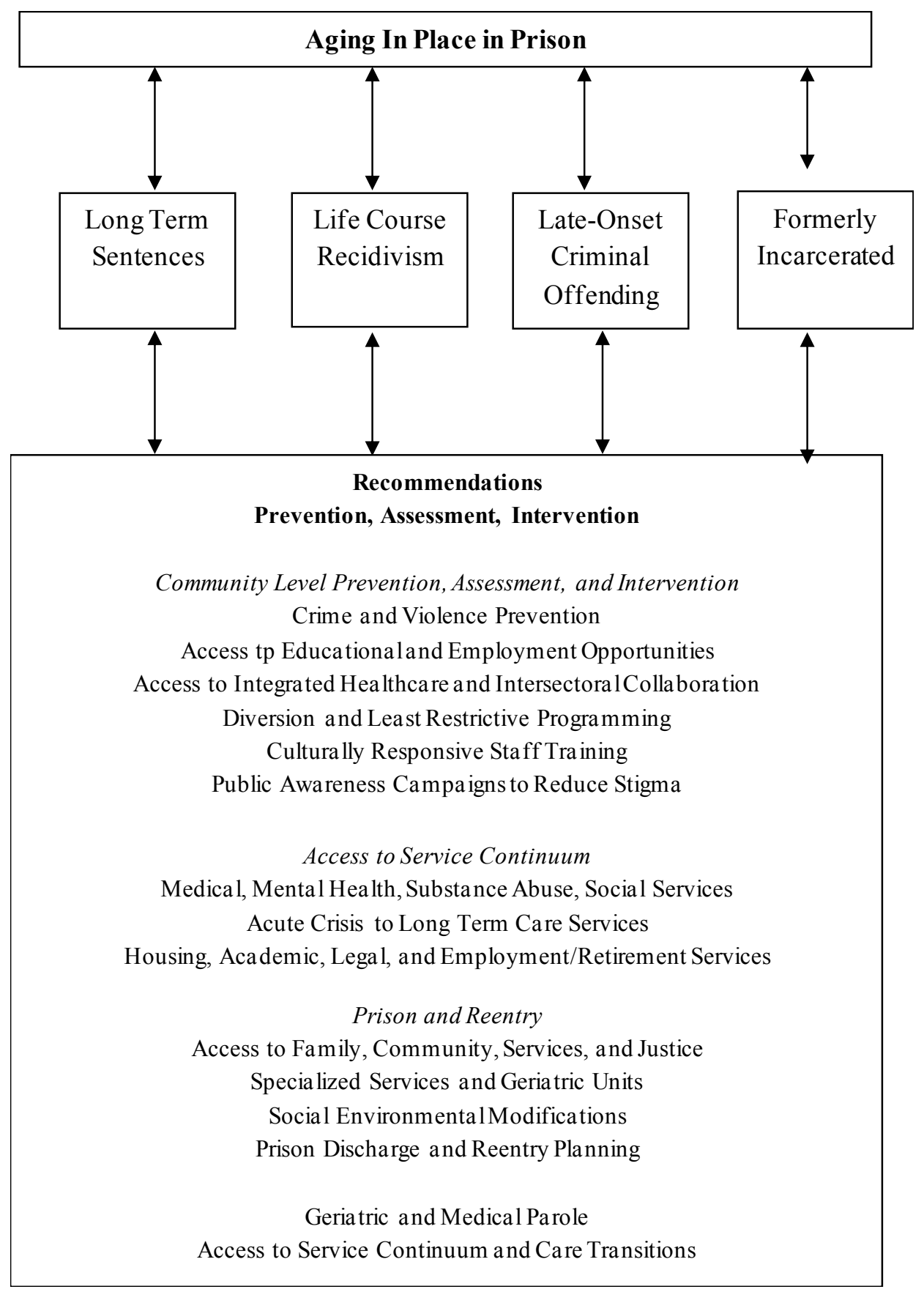

Figure 1. Prevention, assessment and intervention planning for older adults at risk of and/or involved in the criminal justice system

The best case scenario for prevention is for social workers to use research, practice, and advocacy to address health disparities, inequities, and disproportionate effects of incarceration. Older adults reuniting with the community are to provide them with services that match their complexity of needs (see Figure 1). Providing needed resources early enough in the process, such as obtaining social security benefits or housing, may make a significant difference towards successful reintegration (Higgins \& Severson, 2009). Lawyers can provide 
services for many older adults in prison who need legal representation, such as in the case of disabilities or victimization or medical neglect while in prison. Human rights and legislative advocates can assist with ongoing policy and system reform efforts.

Providing a seamless bridge between prison and community is not only a key component of providing individual, family, and community cohesion, health and well-being (Snyder et al., 2009 ), it may also be key to reducing the $\$ 60$ billion in reentry costs that are positioned to increase as more prisoners age with complex health and social care needs (Nunez-Neto, 2008). The promising programs highlighted in this chapter suggest that even correctional staff can overcome over attitudinal and systemic barriers to treat incarcerated aging people and their families with dignity and respect and help make communities safer. If we are to follow our mission, social work must take a leading role in developing services and advocating on behalf and with incarcerated and formerly incarcerated aging people, and their families and communities at the local, national, and global levels. Perhaps most significant is to address wide scale societal stigma and oppression experienced by older people and incarcerated and formerly incarcerated persons. To truly realize a human rights culture in which all individuals are treated with dignity and respect, we must also be willing to embrace aging people with criminal convictions.

\section{References}

Aday, R. H. (2003). Aging prisoners: Crisis in American corrections. Praeger, Westport, CT.

Aday, R. H. (2005). Aging prisoners' concerns toward dying in prison. OMEGA-Journal of Death and Dying, 52, 199-216. http://dx.doi.org/10.2190/CHTD-YL7T-R1RR-LHMN

Aday, R., \& Krabill, J. (2012). Older and geriatric offenders: Critical issues for the 21st Century. In L Gideon (Ed.), Special Needs Offenders in Correctional Institutions (pp. 203-233). Thousand Oaks, CA: Sage Publications.

Aday, R. H., \& Krabill, J. (2011). Women aging in prison A neglected population in the prison system. Boulder, CO: Lynne Rienner Publishers.

Alzheimer's Australia, North South Wales [NSW]. (2014). Dementia in Prison: Discussion Paper \#9. [Online] Available: http://www.fightdementia.org.au/common/files/NSW/20140318-NSW-REP-DementiaInPriso n.pdf (March 1, 2014)

American Civil Liberties Union [ACLU]. (2012). At America's expense: The mass incarceration of the elderly. Washington, DC: Author.

Carstairs, B., \& Keon, D. (2009). Canada's aging population: Seizing the opportunity report. Ontario: Canada: Special Senate Committee on Aging. [Online] Available: http://www.parl.gc.ca/Content/SEN/Committee/402/agei/rep/AgingFinalReport-e.pdf

Chiu, T. (2010). It's about time: Aging prisoners, increasing costs, and geriatric release. New York: Vera Institute of Justice.

Cooney, F., \& Braggins, J. (2010). Doing Time: Good practice with older people in prison 
-the views of prison staff. London: Prison Reform Trust.

Crawley, E., \& Sparks, R. (2005). Hidden injuries? Researching the experiences of older men in English prisons. The Howard Journal of Criminal Justice, 44, 345-356. http://dx.doi.org/10.1111/j.1468-2311.2005.00380.x

Davies, M. (2011). The integration of elderly prisoners: An exploration of services provided in England and Wale. International Journal of Criminology (pp. 1-32). [Online] Available: http://www.internetjournalofcriminology.com/DaviesTheReintegrationofElderlyPrisone.p.pdf

Dawes, J. (2009). Ageing prisoners: issues for social work. Australian Social Work, 62, 258-271. http://dx.doi.org/10.1080/03124070902803475

Grant, A. (1999). Elderly inmates: Issues for Australia. Canberra ACT 2601, Australia. [Online]

Available:

http://www.aic.gov.au/documents/7/0/B/\%7B70B4E5D4-3F91-416B-8670-0E3E4A1FF2AC \%7Dti115.pdf

Guerino, P., Harrison, P., \& Sabol, W. (2011). U.S. Department of Justice, Bureau of Justice Statistics. Prisoners in 2010. [Online] Available: http://bjs.ojp.usdoj.gov/content/pub/pdf/p10.pdf

Hale, L., \& Swiggum, C. (2011, March). Older prisoners pose new challenges for Canada's prisons. UBC Journalism News Service. [Online] Available: http://thethunderbird.ca/2011/03/31/older-prisoners-pose-new-challenges-for-canadas-correcti onal-service/

Harrison, M. (2011). A promising practice-True Grit, paper presented at the Public Forum Aging Prisoners: A Crisis in Need of Intervention, Fordham University, New York, NY, November 2011.

Higgins, D., \& Severson, M. (2009). Community reentry and older adult offenders: redefining social work roles. Journal of Gerontological Social Work Roles, 52, 784-802. http://dx.doi.org/10.1080/01634370902888618

Hill, M. (2007, May 29). New York prison creates dementia unit. The Washington Post. [Online] Available: http://www.washingtonpost.com/wp-dyn/content/article/2007/05/29/AR2007052900208_pf.h tml (August 1, 2011)

Human Rights Watch [HRW]. (2012). Old behind bars: the aging prison population in the United States. [Online] Available: http:/www.Human Rights Watch.org/reports/2012/01/27/old-behind-bars

La Vigne, N. G., \& Cowan, J. (2005). Mapping prisoner reentry: an action research Guidebook. Urban Institute, Justice Policy Center.

Loeb, S. J., Steffensmeier, D., \& Lawrence, F. (2008). Comparing incarcerated and community-dwelling older men's health. Western Journal of Nursing Research, 30, 234-249. 
http://dx.doi.org/10.1177/0193945907302981

Maschi, T., Morgen, K., Zgoba, K., Courtney, D., \& Ristow, J. (2011). Trauma, stressful life events, and post traumatic stress symptoms: Do subjective experiences matter? Gerontologist, 51(5), 675-686. http://dx.doi.org/10.1093/geront/gnr074

Maschi, T., Kwak, J., Ko, E. J., \& Morrissey, M. (2012). Forget me not: Dementia in prisons, The Gerontologist, 52, 441-451. http://dx.doi.org/10.1093/geront/gnr131

Maschi, T., Suftin, S., \& O’Connell, B. (2012). Aging, mental health, and the criminal justice system: a content analysis of the literature. Journal of Forensic Social Work, 2, 162-185. http://dx.doi.org/10.1080/1936928X.2012.750254

Maschi, T., Viola, D., \& Morgen, K. (2013). Trauma and coping among older adults in prison: Linking Empirical Evidence to Practice. Gerontologist. http://dx.doi.org/10.1093/geront/gnt069

Maschi, T., Viola, D., \& Sun, F. (2012). The high cost of the international aging prisoner crisis: well- being as the common denominator for action. The Gerontologist, 2012 Oct 4.

Maschi, T., Viola, D., Morgen, K., \& Koskinen, L. (2013). Trauma, stress, grief, loss, and separation among older adults in prison: The protective role of coping resources on physical and mental wellbeing. Journal of Crime and Justice. http://dx.doi.org/10.1080/0735648X.2013.808853

Maschi, T., Viola, D., Harrison, M., \& Harrison, W. (in press). Bridging community and prison for older adults and their families: Invoking Human Rights and Intergenerational Family Justice. International Journal of Prisoner Health.

Maschi, T., Marmo, C., \& Han, J. (in press). Palliative care in prison: A content analysis of the literature. International Journal of Prisoner Health.

Maschi, T., Morrissey, M., \& Leigey, M. (2013). The case for human agency, well-being, and community reintegration for people aging in prison: A statewide case analysis. Journal of Correctional Healthcare. Published online May 26, 2013. http://dx.doi.org/10.1177/1078345813486445

Maschi, T., Gibson, S., Zgoba, K., \& Morgen, K. (2011). Trauma and life event stressors among young and older adult prisoners. Journal of Correctional Health Care, 17(2), 160-172. http://dx.doi.org/10.1177/1078345810396682

Mesurier, R. (2011). Supporting older people in prison: ideas for practice. [Online] Available: http://www.ageuk.org.uk/documents/en-gb/for-professionals/government-and-society/older\% 20prisoners\%20guide_pro.pdf?dtrk=true

Ministry of Justice. (2010). Offender Management Caseload Statistics 2009. London, England. [Online] Available: http://www.justice.gov.uk/publications/statistics-and-data/prisons-and-probation/omcs-annual .htm 


\section{Macrothink Institute ${ }^{\text {TM }}$}

National Institute of Corrections. (2010). Effectively managing aging and geriatric offenders. [Online] Available: http://nicic.gov/Library/024363 (April 1, 2011)

Nunez-Neto, B. (2008). Offender reentry: correctional statistics, reintegration into the community, and recidivism. [Online] Available: http://lieberman.senate.gov/assets/pdf/crs/offenderreentry.pdf

Organization for Economic Co-operation and Development [OECD]. (2010). Factbook. [Online] Available: http://www.oecdlibrary.org/economics/oecd-factbook-2010_factbook-2010-en

Pennsylvania Department of Corrections v. Yeskey, No. 97-634 (U.S. June 15, 1998).

Pew Charitable Trusts [PCT]. (2010). Collateral costs: incarceration's effect on economic mobility. Washington, DC.

Sampson, R., \& Laub, J. (2003). Life-course disasters? Trajectories of crime among delinquent boys followed to age 70 . Criminology, 41, 555-592. http://dx.doi.org/10.1111/j.1745-9125.2003.tb00997.x

Snyder, C., van Wormer, K., Chada, J., \& Jaggers, J. (2009). Older adult inmates: The challenges for social work. Social Work, 54, 117-124. http://dx.doi.org/10.1093/sw/54.2.117

Ubelacker, S. (2011). Program trains inmate caregivers to watch over aging prisoners with dementia. [Online] Available: http://www.breitbart.com/article.php?id=cp_imtmi6k6c1\&show_article=1 (August 1, 2011)

U.S. Census Bureau. (2010). U.S. popclock projection. [Online] Available: http://www.census.gov/main/www/popclock.html

United Nations. (1948). The universal declaration of human right. [Online] Available: http://www.un.org/en/documents/udhr/

United Nations. (1977). Standard minimum rules for the treatment of prisoner. [Online] Available: http://www2.ohchr.org/english/law/treatmentprisoners.htm

United Nations. (2012). Report of the United Nations High Commissioner for Human Right. Substantive session, 23-27 July 2012 Geneva.

United Nations Office on Drugs and Crime [UNODC]. (2009). Handbook for prisoners with special needs. [Online] Available: http://www.unhcr.org/refworld/docid/4a0969d42.html

Western, B. (2008). From prison to work: a proposal for a national prisoner reentry program. Washington, DC: The Brookings Institution. [Online] Available: http://scholar.harvard.edu/brucewestern/files/12_prison_to_work_western.pdf

Williams, B., McGuire, J., Lindsay, R., Baillargeon, J., Cenzer, I., Lee, S., \& Kushel, M. (2010). Coming home: health status and homelessness risk of older pre-release prisoners. Journal of Gerontological Internal Medicine, 25, 1038-1044. http://dx.doi.org/10.1007/s11606-010-1416-8 


\section{Macrothink}

International Journal of Social Work

ISSN 2332-7278 2014, Vol. 1, No. 1

World Health Organization [WHO]. (2012). Ageing and life course. [Online] Available: http://www.who.int/ageing/projects/elder_abuse/en/

\section{Copyright Disclaimer}

Copyright reserved by the author(s).

This article is an open-access article distributed under the terms and conditions of the Creative Commons Attribution license (http://creativecommons.org/licenses/by/3.0/). 